\title{
Plant Diversity and Cover after Wildfire on Anthropogenically Disturbed and Undisturbed Sites in Subarctic Upland Picea mariana Forest
}

\author{
STEPHANIE NOWAK, ${ }^{1}$ G. PETER KERSHAW ${ }^{2}$ and LINDA J. KERSHAW ${ }^{3}$
}

(Received 23 October 2000; accepted in revised form 27 February 2001)

\begin{abstract}
Postfire development of cover and diversity was studied in an upland Picea mariana-dominated forest in the Canadian Subarctic. Short-term vegetation responses of 10- and 22-year-old cleared rights-of-way and a forest site were investigated two and three growing seasons after a wildfire. Prefire and postfire investigation of the study site allowed direct comparison of species cover and frequency values, as well as the Shannon-Wiener diversity index, before and after the fire. The fire considerably reduced diversity on all sites. Species diversity increased with the level of prefire disturbance. Prefire disturbance influenced the fire's characteristics by altering the fuel load and soil moisture, which in turn affected the postfire revegetation through different soil and microclimatic conditions. The sites that were most severely disturbed before the fire experienced the most rapid revegetation, including the highest diversity index and highest plant cover. Of the sites that were undisturbed before the fire, the natural drainage swales offered the best growing conditions after the burn. Furthermore, prefire disturbance increased the patchiness of the burned area, and the residual flora of unburned patches added to postfire floristic diversity.
\end{abstract}

Key words: Subarctic vegetation, wildfire, industrial corridor, postfire, boreal, succession

RÉSUMÉ. On a étudié le développement du couvert et de la diversité après un incendie dans une forêt de haute terre dominée par Picea mariana, au Canada subarctique. Les réactions à court terme des plantes poussant dans les emprises dégagées vieilles de 10 et 22 ans, ainsi qu'un site forestier ont été l'objet de recherches deux et trois saisons de croissance après un incendie de forêt. Les travaux réalisés sur le site de l'étude avant et après le feu ont permis une comparaison directe du couvert et de la fréquence des espèces ainsi que de l'index de diversité Shannon-Wiener avant et après le feu. L'incendie a considérablement réduit la diversité sur tous les sites. La diversité des espèces augmentait avec le niveau de perturbation existant avant l'incendie. La perturbation pré-incendie a influencé la nature du feu en modifiant la masse de combustible et l'humidité du sol, qui, à leur tour, ont affecté le reverdissement post-incendie en modifiant l'état du sol et les conditions microclimatiques. Les sites qui avaient été le plus perturbés avant le feu ont connu le reverdissement le plus rapide, y compris l'index de diversité et le couvert végétal les plus élevés. Parmi les sites qui n'avaient pas été perturbés avant l'incendie, les dépressions de drainage naturelles offraient les meilleures conditions de croissance après le feu. De plus, la perturbation pré-incendie a intensifié le morcellement de la surface brûlée, et la flore résiduelle des parcelles non brûlées a ajouté à la diversité floristique présente après l'incendie.

Mots clés: végétation subarctique, incendie de forêt, corridor industriel, post-incendie, boréal, succession

Traduit pour la revue Arctic par Nésida Loyer.

\section{INTRODUCTION}

In the boreal forest of northwestern Canada, recurring natural fires have a major effect on the vegetation. Natural disturbances such as large fires are common in the northern forests of North America. Changes to the fire regime have important implications for many parameters in these subarctic ecosystems, including the composition of the vegetation (Payette, 1992).

The impacts of industrial activities in northern ecosystems have altered many ecosystem processes (Heinselman, 1981). Logging activities, roads, land clearing, and activities and facilities associated with the oil and gas industry have had many direct effects on northern ecosystems. As a consequence, the fire regime has been influenced by an increase in ignition sources, by changes in the fuel load, and by the creation of firebreaks (Brown, 1983). Furthermore, damage to or complete removal of vegetation frequently causes changes to the permafrost (Nolte et al., 1998), and these also affect aspects of the fire regime. Awareness of these effects resulted in a number of studies focusing on related environmental alterations, such as active layer changes, revegetation of abandoned disturbances, and changes in microclimate and snowpack characteristics. Two studies have restricted

\footnotetext{
${ }^{1}$ Emil-von-Behring Str. 13, 35041 Marburg, Germany; nowak@ stud-mailer.uni-marburg.de

${ }^{2}$ Corresponding author: Department of Earth and Atmospheric Sciences, University of Alberta, Edmonton, Alberta T6G 2E3, Canada; peter.kershaw@ualberta.ca

${ }^{3}$ Arctic and Alpine Environmental Consulting Services, 51163 Range Road 204, Sherwood Park, Alberta T8G 1E5, Canada

(C) The Arctic Institute of North America
} 
investigation to the direct influences of anthropogenic disturbances on subarctic ecosystems (Felix et al., 1992; Kershaw and Kershaw, 1986), but no study has focused on how anthropogenic disturbances affect the fire regime and the revegetation of burned areas. With increasingly large areas affected by industrial development in the boreal forest, the characteristics of the postfire environment (e.g., revegetation, active layer, soil) should be investigated to determine whether responses of disturbed sites are different from those of areas in a more pristine state.

In the context of this study, "revegetation" includes the reestablishment of prefire communities on the anthropogenic disturbances and in the previously undisturbed forest. This more general term was selected since the communities dominating the anthropogenic disturbances were a response to industrial types of disturbances and differed considerably from the undisturbed forest. It is problematic to use terms such as "community reestablishment" when the prefire community was the result of anthropogenic disturbances 10 or 22 years prior to the fire and its on-site propagules differed from those of the forest. In addition, given the short recovery period, it would be problematic to predict reestablishment of the prefire/preanthropogenic disturbance plant communities. What is presented is the revegetation of the burned areas from onsite and off-site sources during the first three growing seasons after the fire.

The Studies of the Environmental Effects of Disturbances in the Subarctic (SEEDS) research site, which included a simulated transport corridor and undisturbed control stands, was established in 1985 north of the confluence of the Great Bear and Mackenzie Rivers (Fig. 1). In early June 1995, the entire site was burned by a wildfire. Using data collected over the previous 10 years, it was possible to compare prefire and postfire vegetation on the same sites in order to assess the responses to the fire of both natural and anthropogenically disturbed areas.

Studies of revegetation after fire often compare burned areas with nearby unburned patches (e.g., Viereck and Dyrness, 1979), which makes it difficult to differentiate between real on-site succession and natural site variations (Heinselman, 1981). Data collected on the SEEDS site before the fire enabled comparison with postfire data for the same site, so vegetation differences due to site variations between the burned and reference stands were not an issue. Other studies have relied on controlled and managed fires to simulate disturbance, but those studies are limited by the different properties of the applied fire model. Johnson (1992) suggests that fire intensity would have to be high in order to generate and sustain fires that result in large burns. Such intense fires would be impossible to simulate under normal controlled experimental conditions. The intensity of the fire that overran the SEEDS site was sufficient to melt the aluminum blocks of boat motors stored on the site and to melt and deform small-mammal live traps of aluminum and galvanized sheet metal that were deployed over more than half of the site on a trapping grid.
This study aimed to investigate and clarify some of the vegetation responses to a wildfire and the natural revegetation of undisturbed forest and anthropogenically disturbed sites in a subarctic upland forest dominated by Picea mariana (Mill.) BSP. The main focus was on changes in plant cover and species diversity during the first three years following the fire, including a comparison of prefire and postfire communities. Anthropogenic disturbances included a 22-year-old seismic line that had been used as a winter road in 1983-84 and 1984-85 and a simulated transport corridor designed to reflect conditions on smalldiameter pipeline rights-of-way, power transmission corridors, or winter roads.

\section{STUDY AREA}

The SEEDS study area was situated $10 \mathrm{~km}$ north of Tulita, Northwest Territories, in the Canadian Subarctic, west of the Norman Range near the confluence of the Mackenzie and Great Bear Rivers $\left(64^{\circ} 58^{\prime} \mathrm{N}, 125^{\circ} 35^{\prime} \mathrm{W}\right)$ at an altitude of $175 \mathrm{~m}$ (Fig. 1). The Mackenzie Valley is a zone of high fire risk because of the intensity and frequency of interactions between high- and low-pressure weather systems that produce thunderstorms and lightning (Timoney and Wein, 1991). In the vicinity of Norman Wells, over half the wildfires during 1970-74 occurred in June, and almost $40 \%$ occurred in July (Rowe et al., 1975). The study area was situated north of the closed crown forest zone, in an area classed by Payette (1992) as lichenspruce woodland, where tree cover is less than $40 \%$. Before 1995, an open-canopied, homogeneous Picea mariana-dominated forest about 300 years old covered the area (Kershaw, 1987), with tree cover ranging from $10 \%$ to $30 \%$. The area was classified as a decadent stand because of its age, open structure, stunted tree growth form, and the high amount of standing dead matter. This site was selected for the SEEDS study to represent the older stands in the region, where fires have produced a mosaic of stand ages. The older stands have a number of environmental characteristics that were desirable for the original study, including thaw-susceptible permafrost, a shallow active layer, and a thick, peaty (organic matter $[\mathrm{OM}]$ ) surface layer (Kershaw, 1987).

The SEEDS study, initiated in 1985, encompassed an area of approximately 4.3 ha. As part of the study, a rightof-way (ROW) was cleared of trees and shrubs, but the surface vegetation was left intact. Forested areas between the arms of the S-shaped ROW were left undisturbed. The undisturbed forest was criss-crossed by natural swales that drained runoff to a wetland in the valley north of the site (Fig. 2). The study area lay adjacent to a seismic line created during hydrocarbon exploration in $1972-73$. This seismic line was used as a winter road in 1983-84 and $1984-85$ and is still used each winter as a snowmobile trail. Consequently, shrubs and trees protruding above the snowpack have been damaged repeatedly over the years. 


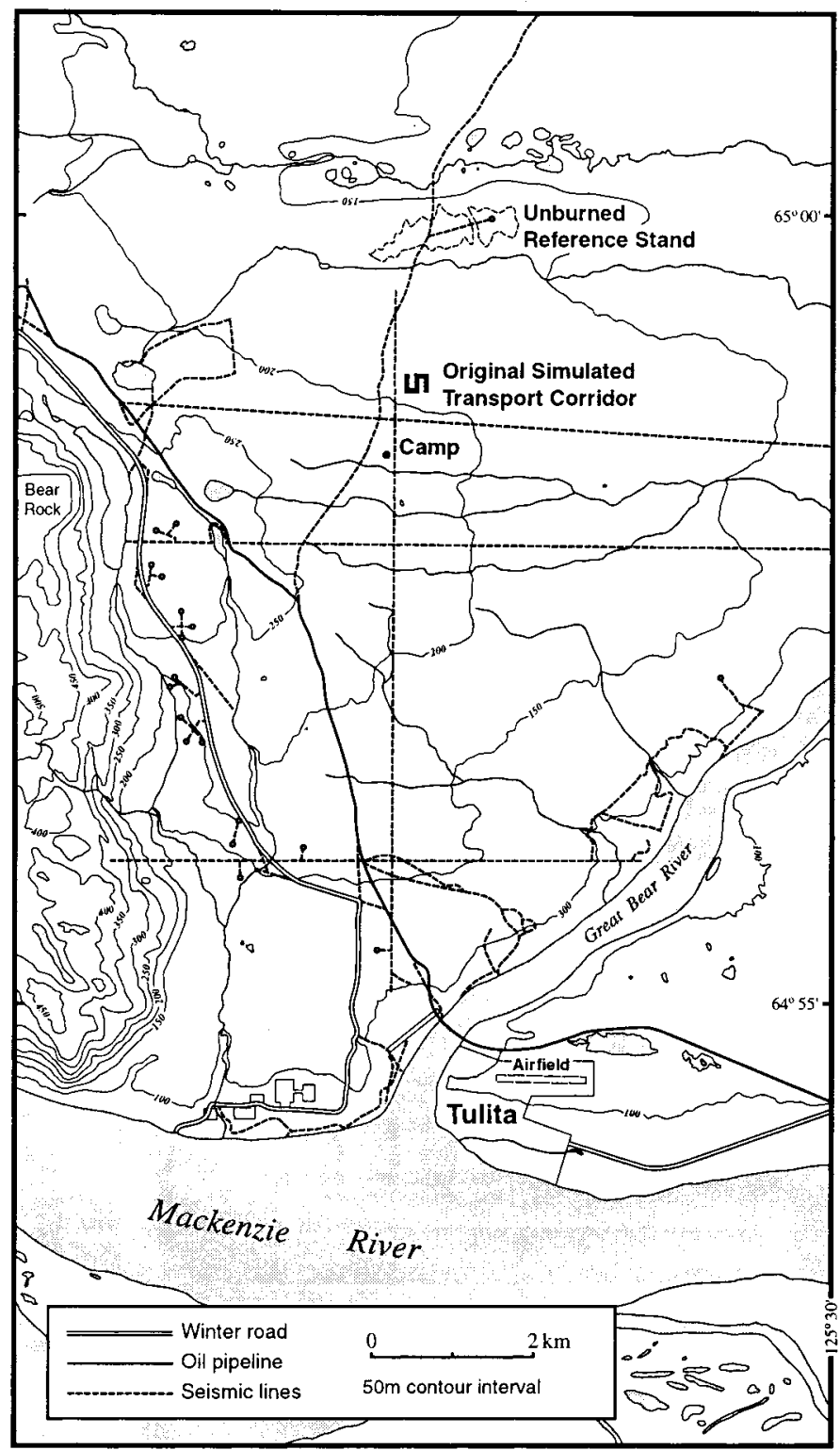

FIG. 1. The original SEEDS site was approximately $10 \mathrm{~km}$ north of Tulita, Northwest Territories. The new, unburned forest reference stand chosen after the June 1995 wildfire was located in a 20 ha unburned remnant $2.5 \mathrm{~km}$ north of the original research site.

Furthermore, the seismic line has been used each summer since the establishment of the SEEDS camp in 1985 by both foot traffic and all-terrain vehicles. Clear-cutting of the right-of-way and of the seismic line induced a topographical lowering as a result of increased active layer depth and consequent surface subsidence (Nolte et al., 1998).

On 6 June 1995, the study area was burned by a wildfire that swept through the camp, eventually consuming 58500 ha of forest. The fire started south of Tulita, across the Great Bear River, in a smouldering subsurface coal layer that had been ignited by a burn the previous year. This high-intensity crown fire killed almost all trees in the area, leaving only small patches of unburned forest. It is estimated that after jumping the Great Bear River, the fire took 30 minutes to travel the 3.5 to $5 \mathrm{~km}$ (depending on where

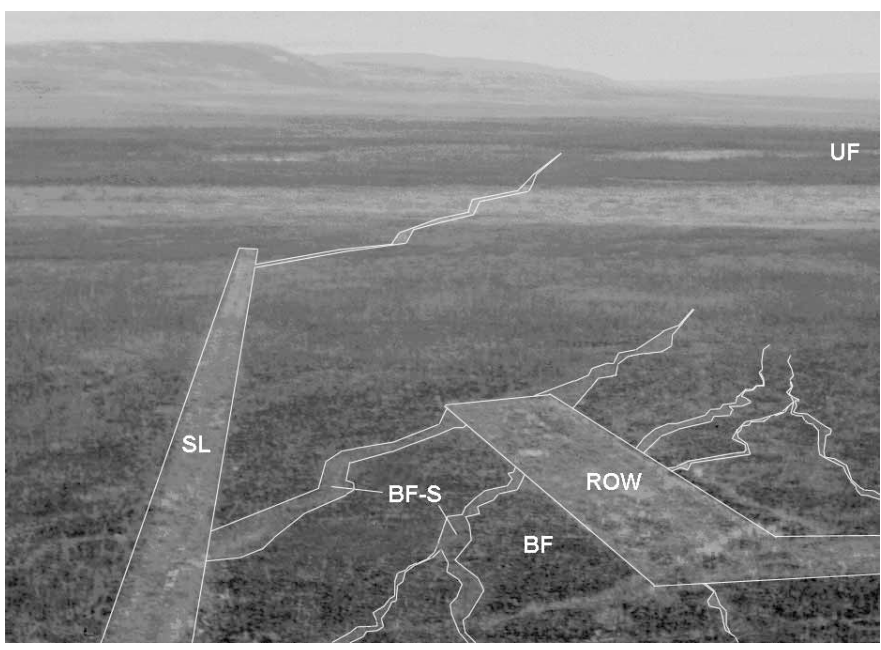

FIG. 2. The simulated transport corridor right-of-way (ROW) is $25 \mathrm{~m}$ wide. The seismic line (SL), unburned forest reference stand (UF), burned forest (BF), and drainage swales (swales) are visible in this July 1977 photo.

it crossed the river) to the SEEDS site. Detailed prefire vegetation data for the SEEDS site (anthropogenically disturbed and undisturbed areas) provided unique baseline date for comparing prefire vegetation to postfire vegetation at the same location.

\section{METHODS}

For data collection, four different burned sites within or immediately adjacent to the original SEEDS site were chosen: one from the ROW; two from the prefire undisturbed forest site, including swales (BF-S) and inter-swale areas (BF); and one on the seismic line (SL) (Fig. 2). In 1985, when the SEEDS study began, the site was wholly within a 300-year-old Picea mariana-dominated upland stand with a continuous lichen-dominated ground cover. All study sites were close together, and all had the same aspect (oriented north-south), slope angle, and soil conditions. A randomized block approach to sampling was selected, in which the size of one arm of the cleared ROW $(180 \times 25 \mathrm{~m})$ became the block size for each of the sites. Within these sites, 30 to 38 vegetation-sampling quadrats were randomly placed on a $1 \times 1 \mathrm{~m}$ grid. The prefire sampling protocol called for 30 randomly located plots, but after the fire the swales were so obviously different that an additional eight quadrats were randomly located within the swale areas to provide more details about them and to reduce their impact on the analysis.

\section{Vegetation Sampling and Analysis}

Plant cover data were collected during late July or early August in 1987 in the BF and on the ROW (Kershaw, 1988), in 1996 in the BF and on the ROW (Kershaw, unpubl. data), and in 1997 in the BF, on the ROW, and on the SL (Nowak, 1999). Cover values under $10 \%$ were 
estimated to the nearest $1 \%$, and those over $10 \%$ were estimated to the nearest $5 \%$. Taxa with less than $1 \%$ cover were assigned a value of $0.3 \%$. When applicable, the cover data were collected for different strata. These included three height categories: $0-30 \mathrm{~cm}, 31-100 \mathrm{~cm}$, and more than $1 \mathrm{~m}$. This stratification sometimes resulted in total cover values well over $100 \%$. The cover data were collected from randomly located $1 \mathrm{~m}^{2}$ quadrats. In 1987, 30 plots on the ROW and 30 plots in the BF (then unburned) were assessed. In 1996 and 1997, we assessed 38 quadrats on the ROW, 38 in the BF, and 38 in a new, unburned reference stand (Fig. 1). Before the fire, differences between drainage swales and interswale plots were not evident, and in many cases vegetation differences were not revealed while traversing the site. After the wildfire, however, differences were dramatic. We felt that the eight postfire plots that were randomly located in swales were sufficiently different that additional plots should be added to ensure that 30 plots were sampled from the interswale areas, keeping sample sizes similar to those of the prefire period. Sample numbers were then increased on all sites to ensure postfire comparability. The vegetation on the SL was assessed only in 1997 , within a $10 \times 100 \mathrm{~m}$ block. The permanent markers for the 1987 plots were lost in the fire, so it was not possible to relocate the quadrats exactly. The cover plots in the BF were classified as either interswale plots or swale plots. Plots were also classified according to fire severity as "heavily burned" ( soil OM burned, and no live vegetation remaining), "lightly burned" (little evidence of OM removal, but above-ground biomass burned), or "unburned."

Prefire data from 1985-87 were available for both the ROW and the BF. No vegetation data were collected during the first growing season immediately after the fire (July-August 1995), but sampling was conducted in the second and third growing seasons (in 1996 and 1997, the first and second postfire years) except on the seismic line, which was sampled only in 1997.

Vascular plant taxonomy follows Porsild and Cody (1980), with species names following Kartesz and Meacham (1999). Nonvascular plant taxonomy follows Anderson et al. (1990), Vitt et al. (1988), and Schuster (1969-82). The data were analyzed using values of plant cover, plant richness, and species diversity. Cover and richness were considered separately for vascular and nonvascular plants. Species richness and species diversity were calculated for each site and year. Sample plots in the BF were stratified to investigate differences between the swale and interswale plots.

Diversity indices are commonly used to assess the state of an ecosystem (e.g., as a criterion for conservation evaluations), with high diversity generally being considered a desirable property in a community or ecosystem (Kent and Coker, 1992). In this study, species richness and species diversity were used to compare the timing and extent of revegetation on burned treatments, burned forest, and an unburned black spruce stand. A species diversity index was used to incorporate both species richness and relative abundance. High diversity does not necessarily reflect a large number of different species (Kent and Coker, 1992). Species richness was defined as the number of species on a site, and species diversity, as the number of abundant species (Alatalo, 1981). The most widely used diversity index is the Shannon-Wiener index $\left(\mathrm{H}^{\prime}\right)$, which combines species richness and relative abundance (Kent and Coker, 1992). It assumes that individuals are randomly sampled from a population and that all species in the vegetation unit are included in the sample. The antilogarithm of Shannon's index, $\mathrm{H}^{\prime}$ simplifies the interpretation because it emphasizes the difference (Peet, 1974). $\operatorname{Exp}\left(\mathrm{H}^{\prime}\right)$ is an index of the number of equally common species in a sample, where each species is weighted by its abundance (Peet, 1974). Consequently, the more species present in a sample and the more even their distribution, the greater the diversity. Species diversity $\left(\exp \left[\mathrm{H}^{\prime}\right]\right)$ was calculated by the formula:

$$
\exp \left(H^{\prime}\right)=-\sum \frac{c_{i}}{N} \ln \left(\frac{c_{i}}{N}\right)
$$

where $c_{i}$ is the cover of species $i, \ln$ is $\log$ base $_{n}$, and $N$ is the maximum cover value of all samples. In contrast to Peet (1974), $N$ does not denote the total plant cover of each sample. This strategy helps to reduce the error caused by samples with low species richness and low cover values and by species-rich samples with high cover values. At low total cover values, the diversity index is not proportional to the number of abundant species, because the applied scaling shifts species with low cover values toward the middle range, and the diversity index increases excessively (Fig. 3). Cover values of less than $1 \%$, where the slope of the scaling function $\left(\mathrm{f}\left(c_{i}\right)=c_{i} \ln \left(c_{i}\right)\right)$ is relatively steep, are a major source of error. This problem requires a different scaling; therefore, $N$ was defined as the maximum cover value of all samples. Consequently, the numbers in this study cannot be compared directly with those of other studies using the Shannon-Wiener index, but they do allow a spatial and temporal comparison between the sites in this study. Because the calculation of evenness is based on the unmodified calculation of $\exp \left(\mathrm{H}^{\prime}\right)$, measurements of evenness became unreliable.

\section{RESULTS}

The unburned forest reference stand was located in the only unburned stand within the region, and its species composition and cover differed somewhat from those of the original SEEDS forest (Table 1). The prefire cover value falls between the values estimated for the two postfire samples in the new, undisturbed reference stand. Species richness differences between the prefire forest and the postfire unburned reference stand were due mainly to lower numbers of nonvascular taxa (Table 1). Tree discs taken from the unburned reference stand were a maximum 
of 96 years old, while the prefire forest was approximately 300 years old at the time of the wildfire (Kershaw, 1987).

Of all the burned sites, the BF was the most severely affected by the fire. Its plant cover decreased from almost complete ground cover, with average cumulative cover values of $137 \%$, to $14 \%$ cover in the second growing season following the burn and 53\% cover by the third growing season (Table 1). Postfire cover was highly variable from one quadrat to the next. The narrow, natural drainage swales that dissected the BF had postfire vegetation patterns different from those of the intervening raised areas. The swales in the BF quickly gained relatively high cover, achieving an average of $55 \%$ in the second growing season after the fire, whereas plant cover was only $5 \%$ on the raised interswale BF plots (Table 1).

The ROW experienced more rapid revegetation than the BF. Mean cover was $28 \%$ in the second growing season after the fire and increased to $73 \%$ in the third growing season (Table 1). As in the BF, postfire revegetation on the ROW was highly variable among the plots. The ROW was not burned as intensely as the surrounding forest, and consequently it contained unburned remnants of kneehigh living trees or shrubs.

On the SL, some burned areas had plants such as Empetrum nigrum L. and fruticose lichens that did not survive in the BF (Table 2). Furthermore, the plant cover on the SL was almost complete by the third growing season (Table 1). Additional evidence that large parts of the SL were minimally affected by the fire was provided by the survival of tree saplings of Larix laricina (DuRoi) Koch, Picea mariana, and P. glauca (Moench) Voss (Table 2) that, judging by size and branch whorls, must have originated after the line was used as a winter road in 1986.

\section{Species Diversity and Species Richness}

The BF had the highest species diversity before the fire (Table 1). BF diversity had decreased by $74 \%$ by the second postfire growing season, but varied considerably within the site (Table 1). Plots in the swales with high plant cover had twice the diversity of other plots. By the third growing season, the diversity index in the swales was almost as high as it had been before the fire, but in other BF plots it had increased only slightly (Table 1). Species richness for all sites decreased from 115 species before the fire to 31 species in the third growing season after the fire. Before the fire, nonvascular species were numerous, but the fire eliminated most of these, and vascular plants became dominant (Tables 1 and 2). Only 7 of the 77 prefire nonvascular species were found in the second growing season after the fire.

On the ROW, species diversity by the second postfire growing season was half of the prefire value (Table 1). In the third growing season, the diversity index was considerably higher than in the BF. Species richness on the ROW followed a trend similar to that of the BF. The prefire dominance of nonvascular species was replaced by dominance of vascular species after the fire. Still, species richness after the fire was higher on the ROW than in the BF.

The SL had the highest postfire species diversity (6.0) of all the sites, even higher than the prefire values of the BF (Table 1). The flora included several species that were absent from the other sites, such as Carex atratiformis Britt., C. disperma Dew., C. norvegica ssp. inferalpina (Wahlenb.) Hultén, Epilobium palustre L., Poa palustris L., Populus tremuloides Michx., and Tofieldia pusilla (Michx.) Pers. (Table 2). The result was the highest postfire species richness (76 species) of all burned sites, with vascular plants clearly dominant.

Plotting the species diversity indices against fire severity (Fig. 4) and degree of prefire disturbance (Fig. 5) revealed that the highest diversity indices correlated with either unburned (BF 87) or lightly burned (SL) sites. Accordingly, low diversity indices coincided with high fire severity. The two unburned forest sites had similar diversity indices ( 5.3 for UF vs. 4.9 for BF87). Within two years of the fire, the swale areas in the BF had a diversity index (4.2) approaching that of the prefire forest, while the highest postfire diversity (6.0) was found in the SL, which had sustained the greatest anthropogenic disturbance before the fire. The ROW, which had been less severely disturbed than the SL, had a diversity index of 2.8, falling between the swale areas and interswale plots of the BF. The lowest diversity (1.8) was found in the BF interswale plots, which had been undisturbed prior to the wildfire. The diversity index for the swale plots (BF-S) was closer to that of the prefire BF (BF87) than to that of the postfire interswale areas (BF) (Table 1, Figs. 4 and 5).

\section{DISCUSSION}

The age difference of 200 years between the prefire forest and the postfire unburned reference stand would account for much of the difference in cover and species richness (Tables 1 and 2). In particular, the 300-year-old forest had three times as many nonvascular taxa as the 100year-old reference stand. The longer period would have permitted colonization and propagation of the lichen species that, through time, eventually dominate older stands like those that existed before the wildfire.

\section{Development of Plant Cover}

Usually, fire in wet and permafrost-influenced terrain does not penetrate deeply into the soil, even though it is hot enough to kill the trees (Viereck, 1973). Postfire revegetation is accomplished by the growth of seeds dispersed from sources outside the burn, seeds surviving in soil and on snags within the burn, and vegetative propagules surviving from below-ground sources (Zasada et al., 1992). Early revegetation in burned stands can be rapid, as shrubs, sedges, and grasses that existed in the stand prior to the fire resprout from roots and rhizomes (Viereck, 1973). All 


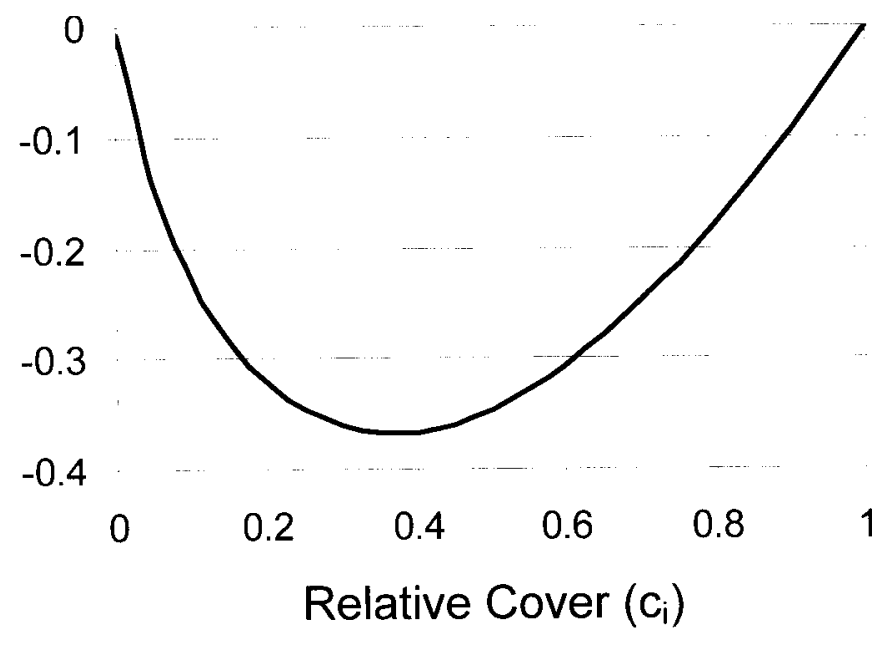

FIG. 3. Scaling function for species diversity.

these strategies, which have been classified by Rowe (1983), were involved in the postfire revegetation of these sites. Chamerion angustifolium Mosquin is an example of an "invader" strategy; the species was absent in the prefire forest and in the unburned forest, but it occupied $60.5 \%$ of the burned forest sample sites after the fire (Table 2). It was present in one prefire quadrat on the ROW, but increased to $78.9 \%$ frequency after the fire. Corydalis sempervirens (L.) Pers., Juncus castaneus Smith, and Picea mariana are examples of "evaders": the first two species were completely absent before the fire and presumably originated from buried seed, while Picea mariana seed was preserved in the canopy (Table 2). Linnaea borealis $\mathrm{L}$. was a species absent before the fire that was probably carried into the burn on the coat of an animal. As such it can be considered an "avoider," since it is a shadetolerant, late-successional species. Nonvascular genera in this group include Cetraria, Cladina, Cladonia, Peltigera, Hylocomium, and Dicranum, which dominated the ground cover prior to the wildfire (Table 2). No species were found that fit the "resisters" classification, an indication of the high severity of the wildfire. "Endurers" were well represented on the site, with shrubs such as Betula nana L., Potentilla fruticosa L., Ledum groenlandicum Oeder, Rosa acicularis Lindl., Salix spp., and Vaccinium spp. resprouting from roots. Other endurers resprouted from rhizomes or stolons preserved in the soil, including Calamagrostis stricta ssp. inexpansa (Gray) C.W. Greene, Carex membranacea Hook, C. vaginata Tausch, Equisetum arvense L., E. scirpoides Michx., and Saussurea angustifolia (Willd.) DC. (Table 2).

The development of vegetation cover after the fire was remarkably different in the three burned sites. A first impression is given by the air photo of the study area (Fig. 2). The light grey of the ROW, the SL, and the swales in the BF, with their higher plant cover, can easily be distinguished from the dark grey of the more intensely burned, less vegetated areas.

Differences between sites in plant cover and species composition reflect different characteristics of the fire at the time of burning and of the sites both before and after the burn. Knee-high shrubs and trees persisting on the SL indicate that this area experienced a less severe fire than the completely burned BF site. On the SL, very little organic soil was exposed, and the few bare patches observed had no evidence of burning. The sporadic distribution of persisting trees and shrubs on the ROW indicated that the fire missed or only lightly burned many patches, and severely burned less than $10 \%$ of the area, but in the adjacent forest it left a continuous blackened organic surface with little or no mineral soil exposed. The BF, with an almost completely blackened surface, supported the lowest plant cover after the burn. The swales were drainageways that were lower and wetter than the adjacent, interswale areas. Consequently, the fire skipped over small patches in the swales, and it did not consume as much organic material on the ground (although it did kill the overstory). The presence of species such as Linnaea borealis L. and Hylocomium splendens (Hedw.) B.S.G. attest to the lack of fire influence, because these "avoiders" have no adaptations to fire (Rowe, 1983).

Both microtopographic variations and anthropogenic disturbances influenced the postfire environment considerably. The postfire patchiness of the plant cover on the study area was greatly influenced by prefire human activity. Natural factors such as soil moisture and fuel loading (Whelan, 1995) also affected the patchiness of the fire on the study site. Since the topographically lower SL and ROW (lowered by post-disturbance surface subsidence upon thawing of excess ice) were moister, the fire severity would have been reduced. The distribution of fuel in the study area was greatly influenced by anthropogenic disturbance. Creation of both the SL and the ROW involved removing the large amount of potential fuel embodied in tall shrubs and trees. Dead organic matter, such as fallen trees, can compose a large proportion of the fuel (Whelan, 1995). An altered fire regime affects many aspects of postfire vegetation structure, including age-class distribution, species mix, landscape mosaics, and fire boundaries (Weber and Flannigan, 1997). The SL had experienced the most severe disturbance, with frequent vehicle traffic and removal of surface organic matter 22 years before the fire (Evans and Kershaw, 1989). The ROW was cleared 10 years before the fire. In both cases, the tree canopy had not redeveloped by the time of the 1995 fire, thus limiting the amount of available fuel. The patchiness of a fire can determine whether viable sources of plant propagules for recolonization remain within the fire boundaries (Whelan, 1995). In this study, the SL, ROW, and BF-S sites all acted as plant refugia where fire-intolerant species such as Larix laricina were able to survive the fire.

\section{The Influence of Fire on Species Diversity}

Prefire undisturbed sites: The shift from high diversity-index values in the prefire BF to low values after the fire was due primarily to the removal of bryophytes and 
TABLE 1. Mean cover, richness, and diversity on prefire sites (1987) compared to two (1996) and three (1997) growing seasons after the 6 June 1995 wildfire on the SEEDS site, Tulita, Northwest Territories.

\begin{tabular}{|c|c|c|c|c|c|c|c|c|c|c|c|c|c|}
\hline \multirow[b]{4}{*}{ Growing Season } & \multicolumn{3}{|c|}{$\begin{array}{c}\text { Right-of-Way } \\
\text { (ROW) }\end{array}$} & \multicolumn{7}{|c|}{$\begin{array}{l}\text { Burned } \\
\text { Forest } \\
\text { (BF) }\end{array}$} & \multirow{4}{*}{$\begin{array}{c}\text { Seismic } \\
\text { Line } \\
(\mathrm{SL})\end{array}$} & \multirow{3}{*}{\multicolumn{2}{|c|}{$\begin{array}{c}\begin{array}{c}\text { Unburned } \\
\text { Forest } \\
\text { (UF) }\end{array} \\
\\
\text { Postfire } \\
\text { Growing } \\
\text { Season }\end{array}$}} \\
\hline & \multirow{3}{*}{ Prefire } & & & \multicolumn{3}{|c|}{ All Sites $^{1}$} & \multicolumn{4}{|c|}{ Postfire Growing Season } & & & \\
\hline & & \multicolumn{2}{|c|}{$\begin{array}{l}\text { Postfire } \\
\text { Growing } \\
\text { Season }\end{array}$} & Prefire & \multicolumn{2}{|c|}{$\begin{array}{c}\text { Postfire } \\
\text { Growing } \\
\text { Season }\end{array}$} & \multirow{2}{*}{$\begin{array}{l}\text { Swale } \\
\text { (BF-S) } \\
\text { 2nd }\end{array}$} & Interswale & $\begin{array}{l}\text { Swale } \\
(\mathrm{BF}-\mathrm{S})\end{array}$ & \multirow{2}{*}{$\begin{array}{c}\text { Interswale } \\
\text { 3rd }\end{array}$} & & & \\
\hline & & $2 \mathrm{nd}$ & 3 rd & & 2 nd & $3 r d$ & & $2 \mathrm{nd}$ & $3 r d$ & & & $2 \mathrm{nd}$ & $3 \mathrm{rd}$ \\
\hline \multicolumn{14}{|l|}{ Cover \% } \\
\hline All species & 91.1 & 27.9 & 72.9 & 137 & 14.0 & 52.6 & 55.5 & 4.9 & 116.7 & 38.2 & 153.8 & 118.2 & 153.1 \\
\hline SD & 20.8 & 26.7 & 31.3 & 26.5 & 27.6 & 38.9 & 45.2 & 2.5 & 39.4 & 20.7 & 28.3 & 32.0 & 35.4 \\
\hline Vascular Plants & 26 & 13.7 & 45.2 & 55.1 & 11.1 & 40.7 & 41.1 & 4.4 & 92.9 & 28.9 & 77.8 & 57.2 & 88.3 \\
\hline SD & 14.7 & 18.6 & 26.1 & 24.2 & 16.1 & 28.2 & 16.7 & 2.4 & 16.8 & 14.0 & 25.3 & 29.6 & 35.7 \\
\hline Non-vascular Plants & 65 & 14.2 & 27.6 & 82.2 & 2.9 & 11.9 & 14.4 & 0.5 & 23.8 & 9.3 & 76.0 & 61.0 & 64.8 \\
\hline SD & 15.6 & 17.8 & 20.3 & 13.2 & 14.4 & 18.9 & 31.0 & 0.5 & 30.9 & 13.3 & 16.4 & 20.8 & 19.0 \\
\hline Organic & 34.9 & 68.3 & 36.2 & 12.5 & 85.1 & 54.2 & 32.9 & 96.9 & 10.6 & 64 & 2.6 & 21.9 & 6 \\
\hline SD & 15.1 & 33.6 & 25.4 & 8.6 & 27.3 & 25.5 & 26.0 & 16.9 & 6.8 & 21.9 & 2.6 & 16.1 & 6.4 \\
\hline \multicolumn{14}{|l|}{ Frequency } \\
\hline All Species & 26.5 & 24.0 & 23.8 & 27.3 & 29.4 & 30.4 & 49.5 & 33.8 & 46.6 & 37.6 & 32.9 & 36.3 & 35.6 \\
\hline Vascular Plants & 28.1 & 26.5 & 29.0 & 34.6 & 30.7 & 32.9 & 51.8 & 34.2 & 51.0 & 39.3 & 35.5 & 33.5 & 33.5 \\
\hline Non-vascular Plants & 25.1 & 18.4 & 15.1 & 23.1 & 23.7 & 22.8 & 40.0 & 31.7 & 32.8 & 31.7 & 27.3 & 39.6 & 37.4 \\
\hline \multicolumn{14}{|l|}{ Richness } \\
\hline All Species & 90 & 45 & 51 & 115 & 31 & 36 & 27 & 24 & 33 & 26 & 76 & 57 & 65 \\
\hline Vascular Plants & 42 & 32 & 32 & 38 & 24 & 27 & 21 & 20 & 25 & 20 & 50 & 32 & 32 \\
\hline Non-vascular Plants & 48 & 13 & 19 & 77 & 7 & 9 & 6 & 4 & 8 & 6 & 26 & 24 & 33 \\
\hline \multicolumn{14}{|l|}{ Diversity } \\
\hline$(\exp ) \mathrm{H}^{\prime}$ & 3.4 & 1.7 & 2.8 & 4.9 & 1.3 & 2.2 & 2.2 & 1.1 & 4.2 & 1.8 & 6 & 5.1 & 5.3 \\
\hline
\end{tabular}

${ }^{1}$ Includes swale and interswale samples.

lichens (Table 1). The lower diversity-index values were due mainly to decreases in species richness. Also, plant regrowth after the fire occurred predominantly in localized patches, thereby reducing overall diversity even further. The BF had a relatively high diversity, but this was due mainly to the more even distribution of species, rather than to greater species richness. In the swales, although species richness was only slightly higher than in the interswale areas, the higher diversity index values indicate a more even distribution of species. Rapid increases in diversity-index values during the early stages of revegetation resulted from increases in species richness and evenness. In northern Quebec, Morneau and Payette (1989) observed a rapid increase of diversity during the first 25 years after fire, followed by a steady decline to a lower but more stable value in the mature forest. On the SEEDS study site, the diversity index value for the BF was already 2.2 by the third growing season, compared to 4.9 in the 300-year-old forest before the fire. The development of diversity was rapid shortly after the fire disturbance.

Prefire disturbed sites: Both species richness and species diversity reflect the influence of anthropogenic disturbance on revegetation after fire. Investigations of disturbances under the influence of fire in tallgrass prairie (Collins, 1987) revealed that a combination of grazing and burning resulted in the highest species diversity. The lowest species diversity was found on ungrazed, unburned sites. In the subarctic boreal forest of the SEEDS site, a similar relationship was evident, although the disturbances were anthropogenic rather than zoogenic. The species diversity on the burned ROW was twice as high as that of the BF (excluding drainage swales). The species diversity of the SL in the third growing season appears to indicate that more severe preburn disturbances, such as bulldozing, result in a greater diversity after fire. This result could be attributed to changes from anthropogenic disturbance in several environmental factors, including increased active layer, reduced fuel load, and increased patchiness. Since the prefire vegetation of the SL was different from that of the undisturbed forest, it is difficult to assess the extent to which this contributed to the plant community after the fire. Species such as Carex gynocrates Wormskj., Geocaulon lividum (Richards.) Fern., Parnassia palustris, and Pedicularis labradorica Wirsing were eliminated on the ROW and BF but were present on the SL after the wildfire (Table 2). Their presence, in addition to the persistence of tree saplings and tall shrubs, suggests a lowseverity fire of short duration, which removed little surface organic matter. These conditions led to high postfire species richness and diversity in areas previously subjected to anthropogenic disturbances.

\section{CONCLUSIONS}

Detailed prefire vegetation data for the SEEDS site (disturbed and undisturbed areas) provided a unique baseline for comparison with revegetation after a wildfire in an 
TABLE 2. Percent frequency of occurrence for species on prefire sites (1987) compared to sites in the third year (1997) after the 6 June 1995 wildfire on the SEEDS site, Tulita, Northwest Territories.

\begin{tabular}{|c|c|c|c|c|c|c|}
\hline \multirow[b]{2}{*}{ Species in strata } & \multicolumn{2}{|c|}{$\begin{array}{l}\text { Right-of-way (ROW) } \\
\text { (ROW) }\end{array}$} & \multicolumn{2}{|c|}{$\begin{array}{l}\text { Burned Forest } \\
\text { (BF) }\end{array}$} & \multirow[t]{2}{*}{$\begin{array}{l}\text { Seismic Line } \\
\text { (SL) }\end{array}$} & \multirow[t]{2}{*}{$\begin{array}{l}\text { Unburned } \\
\text { Forest (UF) }\end{array}$} \\
\hline & Prefire & Postfire & Prefire & Postfire & & \\
\hline \multicolumn{7}{|l|}{ Less than $1 \mathrm{~m}$} \\
\hline Larix laricina & & & 13.3 & & & \\
\hline Picea mariana & & & 73.3 & & & 73.3 \\
\hline Salix arbusculoides & & & 6.7 & & & \\
\hline \multicolumn{7}{|l|}{ 0.3-1 m } \\
\hline Arctagrostis latifolia & 21.1 & & 3.3 & & & \\
\hline Betula nana & 13.2 & & 3.3 & & 7.9 & 36.7 \\
\hline Carex membranacea & 2.6 & & & & & \\
\hline Chamerion angustifolium & 2.6 & & & & & \\
\hline Eriophorum brachyantherum & & & 3.3 & & & \\
\hline Larix laricina & 10.5 & & 33.3 & & & \\
\hline Ledum groenlandicum & 73.7 & & 50.0 & & & 33.3 \\
\hline Picea mariana & 13.2 & & 80.0 & & & 76.7 \\
\hline Potentilla fruticosa & 23.7 & & 36.7 & & & \\
\hline Rosa acicularis & 2.6 & & & & & \\
\hline Salix arbusculoides & 15.8 & & 13.3 & & & \\
\hline Salix glauca & & & & & 7.9 & \\
\hline Shepherdia canadensis & 2.6 & & & & & 3.3 \\
\hline Vaccinium uliginosum & & & & & & 33.3 \\
\hline \multicolumn{7}{|l|}{$0-0.3 \mathrm{~m}$} \\
\hline Alnus viridis ssp. crispa & & & & 2.6 & 2.6 & \\
\hline Andromeda polifolia & 2.6 & & & & & \\
\hline Anemone richardsonii & 2.6 & 5.3 & 3.3 & & & \\
\hline Arctagrostis latifolia & 68.4 & 68.4 & 60.0 & 63.2 & 89.5 & 13.3 \\
\hline Arctostaphylos rubra & 94.7 & 44.7 & 90.0 & 73.7 & 81.6 & 96.7 \\
\hline Arctostaphylos uva-ursi & & & & & & 6.7 \\
\hline Betula nana & 28.9 & 15.8 & 26.7 & 2.6 & 52.6 & 50.0 \\
\hline Betula papyrifera & 2.6 & & & 5.3 & 34.2 & \\
\hline Calamagrostis stricta ssp. inexpansa & 5.3 & 23.7 & 10.0 & 5.3 & 31.6 & \\
\hline Carex aquatilis & 2.6 & & 6.7 & & & 3.3 \\
\hline Carex atratiformis & & & & & 7.9 & \\
\hline Carex capillaris & & & & & 21.1 & 16.7 \\
\hline Carex disperma & & & & & 5.3 & \\
\hline Carex gynocrates & 5.3 & & 6.7 & & 28.9 & 56.7 \\
\hline Carex novegica ssp. inferalpina & & & & & 5.3 & \\
\hline Carex membranacea & 78.9 & 63.2 & 70.0 & 39.5 & 89.5 & \\
\hline Carex nardina & & & 3.3 & & & \\
\hline Carex scirpoidea & & & & & 2.6 & 10.0 \\
\hline Carex vaginata & 52.6 & 42.1 & 26.7 & 13.2 & 73.7 & 100 \\
\hline Carex spp. & & & & & & 16.7 \\
\hline Corydalis sempervirens & & 2.6 & & & & \\
\hline Empetrum nigrum & 55.3 & 2.6 & 60.0 & & 28.9 & 6.7 \\
\hline Chamerion angustifolium & 2.6 & 78.9 & & 60.5 & 36.8 & \\
\hline Epilobium palustre & & & & & 13.2 & \\
\hline Equisetum arvense & 15.8 & 76.3 & 20.0 & 71.1 & 84.2 & 23.3 \\
\hline Equisetum pratense & 2.6 & 2.6 & & & 7.9 & \\
\hline Equisetum scirpoides & 97.4 & 100 & 100 & 100 & 100 & 83.3 \\
\hline Eriophorum brachyantherum & 23.7 & 18.4 & 23.3 & 10.5 & 63.2 & 20.0 \\
\hline Festuca rubra & & & & & 5.3 & \\
\hline Gentianella propinqua & & & & & & 10.0 \\
\hline Geocaulon lividum & 2.6 & & 3.3 & & 5.3 & \\
\hline Platanthera obtusata & & & 3.3 & & & \\
\hline Hedysarum alpinum & & & & & & 6.7 \\
\hline Juncus castaneus & & & & 2.6 & 36.8 & \\
\hline Larix laricina & 36.8 & 5.3 & 43.3 & & 2.6 & 6.7 \\
\hline Ledum groenlandicum & 97.4 & 60.5 & 100 & 84.2 & 86.8 & 93.3 \\
\hline Linnaea borealis & & & & 2.6 & & \\
\hline Amerorchis rotundifolia & 2.6 & 5.3 & 3.3 & & 2.6 & \\
\hline Parnassia palustris & 2.6 & & 3.3 & & 89.5 & \\
\hline Pedicularis labradorica & 2.6 & & 3.3 & & 2.6 & 3.3 \\
\hline Pedicularis sudetica & & & 3.3 & & & \\
\hline Picea glauca & & & & & 68.4 & \\
\hline Picea mariana & 28.9 & 39.5 & 66.7 & 18.4 & 68.4 & 86.7 \\
\hline Poa palustris & & & & & 2.6 & \\
\hline Populus tremuloides & & & & & 7.9 & \\
\hline
\end{tabular}


TABLE 2. Percent frequency of occurrence for species on prefire sites (1987) compared to sites in the third year (1997) after the 6 June 1995 wildfire on the SEEDS site, Tulita, Northwest Territories - continued:

\begin{tabular}{|c|c|c|c|c|c|c|}
\hline \multirow[b]{2}{*}{ Species in strata } & \multicolumn{2}{|c|}{$\begin{array}{l}\text { Right-of-way (ROW) } \\
\text { (ROW) }\end{array}$} & \multicolumn{2}{|c|}{$\begin{array}{l}\text { Burned Forest } \\
\text { (BF) }\end{array}$} & \multirow[t]{2}{*}{$\begin{array}{l}\text { Seismic Line } \\
\text { (SL) }\end{array}$} & \multirow[t]{2}{*}{$\begin{array}{l}\text { Unburned } \\
\text { Forest (UF) }\end{array}$} \\
\hline & Prefire & Postfire & Prefire & Postfire & & \\
\hline \multicolumn{7}{|l|}{ 0- $0.3 \mathrm{~m}$ - continued: } \\
\hline Potentilla fruticosa & 55.3 & 60.5 & 50.0 & 36.8 & 84.2 & 46.7 \\
\hline Pyrola asarifolia & 7.9 & & 30.0 & & & \\
\hline Rhinanthus minor & & & & & 2.6 & \\
\hline Ribes hudsonianum & 2.6 & & & & & \\
\hline Rosa acicularis & 18.4 & 18.4 & 30.0 & 39.5 & 34.2 & \\
\hline Rubus arcticus spp. acaulis & & & & 2.6 & & \\
\hline Rubus chamaemorus & 34.2 & 28.9 & 60.0 & 44.7 & 10.5 & \\
\hline Rumex arcticus & 5.3 & & 6.7 & & & \\
\hline Rumex aquaticus & & & & & 5.3 & \\
\hline Salix arbusculoides & 15.8 & 13.2 & 20.0 & & 36.8 & 3.3 \\
\hline Salix glauca & 2.6 & 5.3 & 6.7 & 2.6 & 10.5 & 6.7 \\
\hline Salix myrtillifolia & 60.5 & 39.5 & 53.3 & 73.7 & 100 & 83.3 \\
\hline Saussurea angustifolia & 28.9 & 39.5 & 40.0 & 28.9 & 47.4 & 16.7 \\
\hline Selaginella sibirica & 2.6 & 2.6 & & & & \\
\hline Tephroseris atropurpurea & 18.4 & & 16.7 & & & \\
\hline Packera cymbalaria & & 7.9 & & 7.9 & 5.3 & 6.7 \\
\hline Shepherdia canadensis & 5.3 & 2.6 & & & 2.6 & 20.0 \\
\hline Solidago multiradiata & & & & & & 6.7 \\
\hline Spiranthes romanzoffiana & 5.3 & 7.9 & & & 31.6 & 3.3 \\
\hline Stellaria longipes & 2.6 & 23.7 & & 7.9 & 21.1 & 10.0 \\
\hline Tofieldia pusilla & & & & & 7.9 & \\
\hline Vaccinium uliginosum & 97.4 & 18.4 & 96.7 & 44.7 & 94.7 & 90.0 \\
\hline Vaccinium vitis-idaea & 100 & 34.2 & 100 & 44.7 & 39.5 & 96.7 \\
\hline Zigadenus elegans & & & & & & 6.7 \\
\hline \multicolumn{7}{|l|}{ Non-vascular species } \\
\hline \multicolumn{7}{|l|}{ Bryophytes } \\
\hline Acrocarpous mosses (unidentified spp.) & 2.6 & & & & & \\
\hline Aulacomnium acuminatum/palustre & 73.7 & 21.1 & 76.7 & 15.8 & 100 & 60.0 \\
\hline Aulacomnium turgidum & & & 3.3 & & & \\
\hline Bryum pseudotriquetrum & 2.6 & & & & 100 & \\
\hline Bryum sp. & 2.6 & & & & 5.3 & \\
\hline Campylium hispidulum & 5.3 & & & & & \\
\hline Campylium stellatum & 5.3 & & 3.3 & & & \\
\hline Ceratodon purpureus & 10.5 & 86.8 & 6.7 & 81.6 & & \\
\hline Cinclidium stygium & & & 3.3 & 2.6 & 18.4 & \\
\hline Desmatodon spp. & & & 3.3 & & & \\
\hline Dicranella heteromalla & & & 6.7 & & & \\
\hline Dicranella sp. & 2.6 & & & & & \\
\hline Dircranella schrebenaria var. robusta & & & & 5.3 & & \\
\hline Dicranella subulata & & & 6.7 & & & \\
\hline Dicranum sp. & 13.2 & & & & & \\
\hline Dicranum amannii & 2.6 & & 6.7 & & & \\
\hline Dicranum angustum & & 5.3 & & & 13.2 & 66.7 \\
\hline Dicranum fuscescens & 10.5 & & 20.0 & & & \\
\hline Dicranum majus & & & 3.3 & & & \\
\hline Dicranum spadiceum & 5.3 & & 16.7 & & & \\
\hline Dicranum sp. & & & 13.3 & & & \\
\hline Dicranum undulatum & 73.7 & & 73.3 & & & \\
\hline Ditrichum flexicaule & 2.6 & & 10.0 & & 42.1 & 76.7 \\
\hline Ditrichum pusillum & & & 3.3 & & & \\
\hline Drepanocladus aduncus & & & & & 2.6 & \\
\hline Drepanocladus revolvens & & & & & 5.3 & 40.0 \\
\hline Hylocomium splendens & 100 & 18.4 & 100 & 10.5 & 78.9 & 76.7 \\
\hline Hypnum sp. & & & 3.3 & & & \\
\hline Jungermanniaceae sp. & & & 3.3 & & & \\
\hline Leptobryum pyriforme & & 2.6 & & & & \\
\hline Lophozia sp. & & & 3.3 & & & \\
\hline Marchantia polymorpha & & 84.2 & & 63.2 & 13.2 & \\
\hline Meesia uliginosa & 5.3 & & 3.3 & & & \\
\hline Myurella julacea & & & 3.3 & & 2.6 & \\
\hline Oncophorus wahlenbergii & & & 6.7 & & & \\
\hline Orthocaulis sp. & & & 6.7 & & & \\
\hline Orthodicranum flagellare & 47.4 & & 43.3 & & & \\
\hline Orthodicranum quadrilobus & & & 3.3 & & & \\
\hline Philonotis fontana & & & & & 2.6 & \\
\hline
\end{tabular}


TABLE 2. Percent frequency of occurrence for species on prefire sites (1987) compared to sites in the third year (1997) after the 6 June 1995 wildfire on the SEEDS site, Tulita, Northwest Territories - continued:

\begin{tabular}{|c|c|c|c|c|c|c|}
\hline \multirow[b]{2}{*}{ Species in strata } & \multicolumn{2}{|c|}{$\begin{array}{l}\text { Right-of-way (ROW) } \\
\text { (ROW) }\end{array}$} & \multicolumn{2}{|c|}{$\begin{array}{l}\text { Burned Forest } \\
\text { (BF) }\end{array}$} & \multirow[t]{2}{*}{$\begin{array}{l}\text { Seismic Line } \\
\text { (SL) }\end{array}$} & \multirow[t]{2}{*}{$\begin{array}{l}\text { Unburned } \\
\text { Forest (UF) }\end{array}$} \\
\hline & Prefire & Postfire & Prefire & Postfire & & \\
\hline \multirow{2}{*}{\multicolumn{7}{|c|}{$\begin{array}{l}\text { Non-vascular species - continued: } \\
\text { Bryophytes }\end{array}$}} \\
\hline & & & & & & \\
\hline \multicolumn{7}{|c|}{ Pleurocarpous mosses (unidentified spp.) } \\
\hline Pohlia nutans & & & 3.3 & & & \\
\hline Ptilidium pulcherrimum & 44.7 & & 56.7 & & & \\
\hline Ptilidium ciliare & & & & & & 23.3 \\
\hline Tomenthypnum nitens & 63.2 & 18.4 & 80.0 & 21.1 & 100 & 83.3 \\
\hline \multicolumn{7}{|l|}{ Lichens } \\
\hline Cetraria cucullata & 5.3 & & 3.3 & & & 3.3 \\
\hline Cetraria ericetorum & & & 3.3 & & & \\
\hline Cetraria islandica & 7.9 & & 10.0 & & & 3.3 \\
\hline Cetraria nivalis & 42.1 & & 30.0 & & 2.6 & 36.7 \\
\hline Cetraria tilesii & & & & & & 16.7 \\
\hline Cetraria sp. & & & & & & 20.0 \\
\hline Cladina arbuscula & 73.7 & & 76.7 & & & \\
\hline Cladina mitis & 15.8 & 13.2 & 16.7 & & 21.1 & 96.7 \\
\hline Cladina rangiferina & 26.3 & & 23.3 & & & 6.7 \\
\hline Cladina stellaris & 10.5 & & 16.7 & & & 30.0 \\
\hline Cladonia amaurocraea & 44.7 & & 50.0 & & & \\
\hline Cladonia botrytes & 21.1 & 2.6 & 16.7 & & & 13.3 \\
\hline Cladonia cariosa & & 5.3 & & & & 50.0 \\
\hline Cladonia cenotea & 10.5 & & 23.3 & & & \\
\hline Cladonia chlorophaea group & 34.2 & 7.9 & 40.0 & & & 6.7 \\
\hline Cladonia coccifera & 36.8 & 2.6 & 30.0 & & & 26.7 \\
\hline Cladonia cornuta & 76.3 & 5.3 & 70.0 & & & 76.7 \\
\hline Cladonia cyanipes & & & 6.7 & & & \\
\hline Cladonia deformis & 18.4 & & 26.7 & & & \\
\hline Cladonia digitata & & & 3.3 & & & \\
\hline Cladonia ecmocyna & 2.6 & & 23.3 & & & \\
\hline Cladonia fimbriata & 68.4 & & 73.3 & & & \\
\hline Cladonia gracilis & 71.1 & 5.3 & 53.3 & & & 86.7 \\
\hline Cladonia major & & & 3.3 & & & \\
\hline Cladonia metacorallifera & 5.3 & & 3.3 & & & \\
\hline Cladonia multiformis & & & & & 7.9 & \\
\hline Cladonia norlinii & & & 3.3 & & & \\
\hline Cladonia phyllophora & 5.3 & & 16.7 & & & 3.3 \\
\hline Cladonia pleurota & 2.6 & & & & & \\
\hline Cladonia pocillum & 2.6 & & & & & \\
\hline Cladonia pyxidata & 5.3 & 5.3 & 26.7 & & 26.3 & 70.0 \\
\hline Cladonia sp. & & 2.6 & & & & 3.3 \\
\hline Cladonia squamules & 68.4 & & 40.0 & & 7.9 & \\
\hline Cladonia subfurcata & 34.2 & & & & & \\
\hline Cladonia subulata & 7.9 & & 60.0 & & & \\
\hline Cladonia turgida & & & 3.3 & & & \\
\hline Cladonia uncialis & & & 10.0 & & & 3.3 \\
\hline Cladonia verticillata & & 2.6 & 10.0 & & & 13.3 \\
\hline Hypogymnia sp. & & & & & & 80.0 \\
\hline Parmeliopsis sp. & & & & & 2.6 & 40.0 \\
\hline Peltigera aphthosa & 60.5 & 7.9 & 66.7 & 5.3 & 36.8 & 76.7 \\
\hline Peltigera canina & 2.6 & & 3.3 & & & \\
\hline Peltigera malacea & 2.6 & & & & 2.6 & 20.0 \\
\hline Peltigera scabrosa & 10.5 & & 16.7 & & & \\
\hline Peltigera sp. & & & & & & 10.0 \\
\hline Phaeophyscia orbicularis & & & & & & 6.7 \\
\hline Stereocaulon alpinum & 2.6 & & & & & 3.3 \\
\hline Stereocaulon sp. & 5.3 & & & & & \\
\hline Stereocaulon tomentosum & & & & & & 36.7 \\
\hline Organic & 100 & 100 & 100 & 100 & 86.8 & 80.0 \\
\hline Water & & 2.6 & & 7.9 & 28.9 & \\
\hline Mineral & & & & 7.9 & & 3.3 \\
\hline Sample size & 38 & 38 & 30 & 38 & 38 & 31 \\
\hline
\end{tabular}




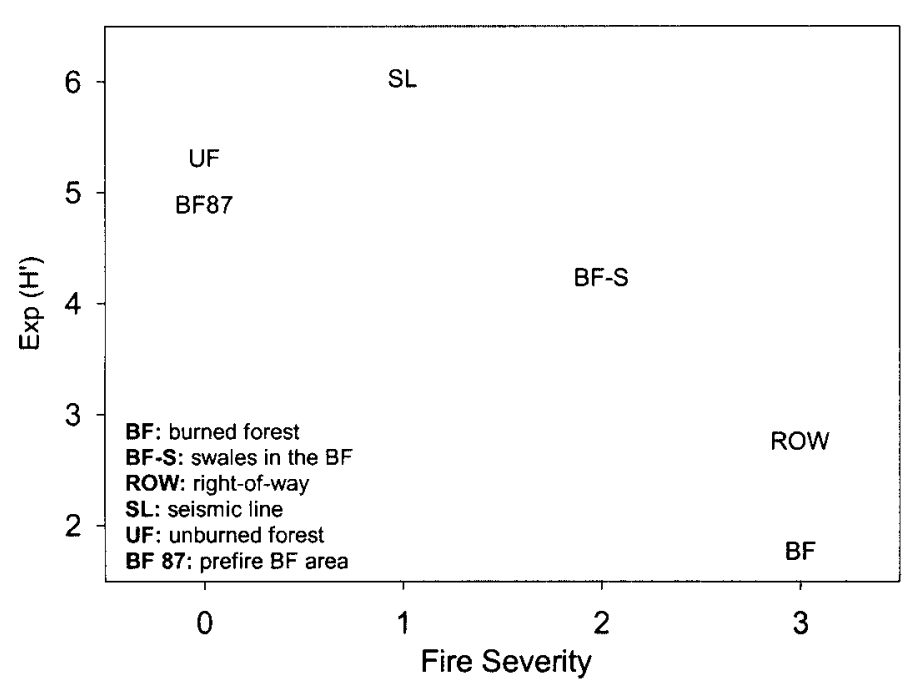

FIG. 4. Species diversity vs. fire severity (data from third postfire growing season, except for the BF87 data, which were collected in 1987). Average site fire severity index: $\mathbf{0}$ for unburned areas; $\mathbf{1}$ for areas where light surface fire removed dried herbaceous material but left shrubs and trees intact; $\mathbf{2}$ for burned areas where most above-ground biomass was burned but with little evidence of OM removal; and $\mathbf{3}$ for heavily burned areas in which above-ground biomass was burned, plants died, and burning into the OM occurred.

upland subarctic forest. Assessment of ecological system integrity using the Shannon-Wiener index $\exp \left(\mathrm{H}^{\prime}\right)$, corrected to avoid distortion at exceptionally low cover values, revealed that anthropogenically disturbed sites supported greater species diversity after a wildfire than sites that were undisturbed before burning. The age of a disturbance also influenced species diversity: the oldest disturbed site (SL) had the highest diversity index, even higher than that of the unburned 300-year-old forest. Thus a high diversity index can indicate ecological disequilibrium rather than relatively natural, undisturbed vegetation, so this should be considered when using diversity indices to evaluate the natural state of an ecosystem.

The patchiness of the fire, caused by prefire anthropogenic disturbances, created small, localized refugia where plants that were not adapted to fire could survive. The persistence of these plants increased the rate and success of colonization by species that could otherwise take many years to become established. In undisturbed areas, drainage swales provided similar refugia for fire-intolerant plants. These micro-sites offered the best postfire growing conditions in the burned forest.

Further studies of the influence of prefire disturbance in the Subarctic might focus on more intense fires that consume organic matter and leave mineral soil exposed. Many studies have stressed the advantage of mineral soil seedbeds for seedling establishment. In this forest, a fire that removed the organic surface soil layer would consume most of the soil seed bank and plant parts capable of vegetative propagation. The fire at this study site did not consume all the organic surface layer and so the partially intact seed bank was a source of propagules for revegetation of the severely disturbed sites.

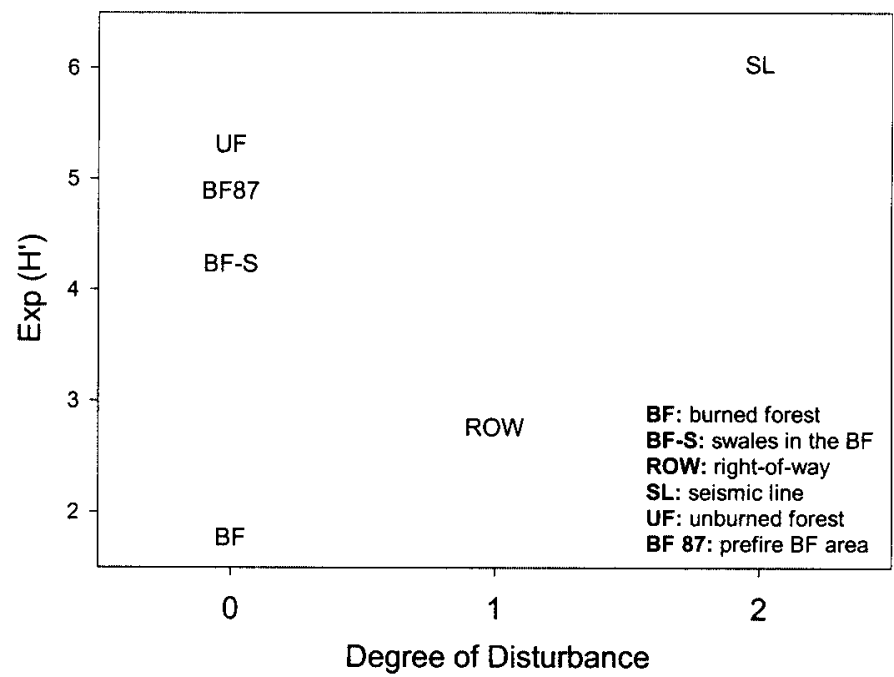

FIG. 5. Species diversity vs. degree of prefire disturbance (data from 1997 except for the BF87 data, which were collected in 1987). Disturbance value: $\mathbf{0}$ for areas undisturbed prior to the 1995 wildfire; $\mathbf{1}$ for areas cleared of tree and erect shrub cover in 1985; and $\mathbf{2}$ for areas bladed during seismic exploration in $1972-73$.

\section{ACKNOWLEDGEMENTS}

Enbridge Pipelines Inc. provided much appreciated logistical support from the commencement of these studies. Alasdair Veitch and Richard Popko, Department of Resources, Wildlife and Economic Development, Government of the Northwest Territories, were on the scene immediately after the fire and provided photos of the site and logistical support. Funding of the SEEDS project originally came from the NOGAP fund through the Canadian Forestry Service under Steve Zoltai's supervision. NSERC support to G.P. Kershaw was supplemented by support from the Canadian Circumpolar Institute and the Royal Canadian Geographic Society to students working on various projects on the site. Significant and much appreciated logistical support was also provided by Bea and Blair Jensen of Ursus Aviation.

\section{REFERENCES}

ALATALO, R.V. 1981. Problems in the measurement of evenness in ecology. Oikos 37:199-204.

ANDERSON, L.E., CRUM, H.A., and BUCK, W.R. 1990. List of the mosses of North America north of Mexico. The Bryologist 93(4):448-499.

BROWN, R.J.E. 1983. Effects of fire on the permafrost ground thermal regime. In: Wein, R.W., and MacLean, D.A., eds. The role of fire in northern circumpolar ecosystems. SCOPE 18. Chichester: John Wiley \& Sons. 97-110.

COLLINS, S.L. 1987. Interaction of disturbances in tallgrass prairie: A field experiment. Ecology 68:1243-1250.

EVANS, K.E., and KERSHAW, G.P. 1989. Productivity of agronomic and native plants under various fertilizer and seed application rates on a simulated transport corridor, Fort Norman, 
Northwest Territories. In: Proceedings of the Conference: Reclamation, A Global Perspective. Alberta Conservation and Reclamation Council Report No. RRTAC 89-2. 81-90.

FELIX, N.A., RAYNOLDS, M.K., JORGENSON, J.C., and DUBOIS, K.E. 1992. Resistance and resilience of tundra plant communities to disturbance by winter seismic vehicles. Arctic and Alpine Research 24:69-77.

HEINSELMANN, M.L. 1981. Fire and succession in conifer forests of northern North America. In: West, C., Shugart, H.H., and Botkin, D.B., eds. Forest succession: Concepts and application. New York: Springer. 374-406.

KARTESZ, J.T., and MEACHAM, C.A. 1999. Synthesis of the North American flora. Biota of North America Program, North Carolina Botanical Gardens, University of North Carolina at Chapel Hill. CD-ROM V. 1.0.

KENT, M., and COKER, P. 1992. Vegetation description and analysis: A practical approach. London: Bellhaven Press.

KERSHAW, G.P. 1987. Year-end report 1986-87. Studies of the environmental effects of disturbances in the Subarctic, S.E.E.D.S. Edmonton: University of Alberta. 45 p.

KERSHAW, L.J. 1988. Vegetation alteration three growing seasons after tree canopy removal in a Subarctic Picea mariana forest. In: Kershaw, G.P., ed. Year-end report 1987-88. Studies of the environmental effects of disturbances in the Subarctic, S.E.E.D.S. Edmonton: University of Alberta. 52-73.

KERSHAW, L.J., and KERSHAW, G.P. 1986. Natural vegetation of man-induced tundra disturbances along the Dempster Highway, Y.T./N.W.T. B.C. Geographical Series 44:151-166.

MORNEAU, C., and PAYETTE, S. 1989. Postfire lichen-spruce woodland recovery at the limit of the boreal forest in northern Quebec. Canadian Journal of Botany 67:2770-2782.

NOLTE, S., KERSHAW, G.P., and GALLINGER, B. 1998. Thaw depth characteristics over five thaw seasons following installation of a simulated transport corridor, Tulita, NWT, Canada. Permafrost and Periglacial Processes 9:71-85.

NOWAK, S. 1999. Early revegetation after natural fire in the boreal forest of northwest-Canada. Diplomarbeit, Marburg: PhillipsUniversität. $125 \mathrm{p}$.

PAYETTE, S. 1992. Fire as a controlling process in the North American boreal forest. In: West, C., Shugart, H.H., and Botkin,
D.B., eds. Forest succession: Concepts and application. New York: Springer. 144-169.

PEET, R.K. 1974. The measurement of species diversity. Annual Review of Ecology and Systematics 5:285-307.

PORSILD, A.E., and CODY, W.J. 1980. Vascular plants of continental Northwest Territories, Canada. Ottawa: National Museums of Canada. 667 p.

ROWE, J.S., SPITTLEHOUSE, D., JOHNSON, E., and JASIENIUK, M. 1975. Fire studies in the upper Mackenzie Valley and adjacent uplands. ALUR74-75-61. Arctic Land Use Research Program, Northern Economic Development Branch, Department of Indian Affairs and Northern Development. 128 p.

SCHUSTER, R.M.S. 1969-82. The Hepaticeae and Anthocerotae of North America. Vols. I-VI. New York: Columbia University Press.

TIMONEY, K.P., and WEIN, R.W. 1991. The areal pattern of burned tree vegetation in the Subarctic region of northwestern Canada. Arctic 44:223-230.

VIERECK, L.A. 1973. Wildfire in the taiga of Alaska. Quaternary Research 3:465-495.

- 1983. The effects of fire in Picea mariana ecosystems of Alaska and northern Canada. In: Wein, R.W., and MacLean, D.A., eds. The role of fire in northern circumpolar ecosystems. SCOPE 18. Chichester: John Wiley \& Sons. 201-220.

VIERECK, L.A., and DYRNESS, C.T. 1979. Ecological effects of the Wickersham Dome fire near Fairbanks, Alaska. General Technical Report PNW-90. Portland, Oregon: Forest Service, U.S. Department of Agriculture. 71 p.

VITT, D.H., MARSH, J.E., and BOVERY, R.B. 1988. Mosses, lichens and ferns of northwest North America. Edmonton: Lone Pine Publishing. 296 p.

WEBER, M.G., and FLANNIGAN, M.D. 1997. Canadian boreal forest ecosystem structure and function in a changing climate: Impact on fire regimes. Environmental Review 5:146-166.

WHELAN, R.J. 1995. The ecology of fire. Cambridge: Cambridge University Press.

ZASADA, J.C., SHARIK, T.L., and NYGREN, M. 1992. The reproductive process in boreal forest trees. In: West, C., Shugart, H.H., and Botkin, D.B., eds. Forest succession: Concepts and application. New York: Springer. 85-125. 